\title{
Lisans Düzeyinde Turizm Eğitimi Alan Öğrencilerin Yılmazlık, Umutsuzluk Durumları ve Sektörel Tutumlarının Kariyer Seçimleri Üzerine Etkileri
}

\author{
The Effect of Resilience, Hopelessness and Sectoral Attitudes of the \\ Students Having Tourism Education at Universities to Their Choices
}

Yrd. Doç. Dr. Burcu ILGAZ YILDIRIM

Akdeniz Üniversitesi

Manavgat MYO

E-posta: burcuilgazyildirim@akdeniz.edu.tr
Doç. Dr. Boran TOKER

Alanya Alaaddin Keykubat Üniversitesi

İşletme Fakültesi

E-posta: boran.toker@alanya.edu.tr

Öz

$\mathrm{Bu}$ araştırma, lisans düzeyinde turizm eğitimi alan öğrencilerin umutsuzluk, yılmazlık durumları ve sektörel tutumlarının kariyer seçimlerine etkilerini belirlemek amacıyla yapılmıştır. Bu amaç doğrultusunda konuyla ilgili literatür araştırması yapılarak çalışmanın teorik bölümü hazırlanmıştır. Turizm eğitimi alan öğrencilerin yılmazlık durumlarının kariyer seçimlerine etkisinin tespitine yönelik yapılan analizlerde yılmazlık faktörleri ile negatif yönlü ilişkiler olduğu tespit edilmiştir. Turizm eğitimi alan öğrencilerin kariyer seçimi ile umutsuzluk ölçeği faktörleri arasında, motivasyon kaybı ile kariyer seçimi arasında herhangi bir ilişki bulunmamışken gelecekle ilgili beklentiler ve umut ile ters yönlü ilişki olduğu tespit edilmiştir.

Anahtar Kelimeler: Yılmazlık, Umutsuzluk, Kariyer seçimi, Turizm eğitimi

\begin{abstract}
This study has been made to determine the effects of resilience, hopelessness and sectoral attitudes of the students having tourism education at universities to their career choices. In accordance with this purpose, theoretical part of the study has been made from the literature related with the subject. Negative relationship with the resilience factors was obtained from the analysis that were made to determine the effects of resilience to career choice. Although, no relationship seen between the career choice and hopelessness scale factors and between career choice and motivation loss of the students having tourism education, an inverse correlation determined between the future expectations and hope.
\end{abstract}

Keywords: Resilience, Hopelessness, Career choice, Tourism education 


\section{Giriş}

Turizm sektörünün emek-yoğun özelliğe sahip olması, üretim ve sunumun insan kaynağına dayanması ve eş zamanlı olması; içinde yaşanılan sibernetik çağa rağmen, iş görenlerin önemini açığa çıkarmaktadır (Üngüren, 2007:1). Turizm sektöründe rekabette üstünlük sağlamada turizm eğitimi almış işgücünün önemini destekleyen birçok ülkede turizm eğitimi veren okullar açılmaktadır. Turizm eğitimi alan öğrencilerin kazandıkları bilgi ve becerileri mezuniyet sonrasında turizm endüstrisinde uygulamaları sektörün bilinçli olarak gelişmesine katkı sağlayacaktır. Turizm eğitimi alan kişilerin, mezuniyet sonrasında sektörde çalışmaya devam etmemesi önemli bir sorun haline gelmektedir. Turizm sektöründe beklenen kaliteli hizmetin sunulmasında en önemli unsur olan nitelikli işgücünün eğitim sonrası sektörde çalışmama nedenlerinin belirlenmesi ve bu konuda gerekli önlemlerin alınması gerekliliği ortaya çıkmaktadır (Pehlivan, 2007:2). Lisans düzeyinde turizm eğitimi alan öğrencilerin kariyer seçimlerini birçok faktör etkilemektedir. Çalışma kapsamında lisans düzeyinde turizm eğitimi alan öğrencilerin yılmazlık, umutsuzluk durumları ve sektörel tutumlarının kariyer seçimlerine etkisi ölçülmüştür.

Kariyer, bir meslek veya bir örgütten ziyade bireysel bir özelliktir (Greenhaus, 1994:4). İşletmeler son zamanlarda, profesyonel kariyer kavramı üzerinde durmakta ve işgörenlerini bu doğrultuda güdülemektedir. Burada ana sorumluluk kuruma düşmektedir. Fakat işgörenlerinde kariyer oluşturma ve geliştirmede önemli sorumlulukları vardır (Güneş, 2006:59). Kariyer iki boyuttan oluşmaktadır. Bunlar; dışsal boyut olarak adlandırılan gerçekçi ve objektif algılamalar ile içsel boyut olarak adlandırılan sübjektif algılamalardır (Şimşek ve diğ., 2004:15). Örgütte gelişmenin sübjektif boyutu olan kariyerin içsel boyutu; bireyin kişiliğinde oluşacaktır (Adıgüzel, 2008: 9). Kariyerin dışsal boyutu; belli bir işe yönelmiş olan objektif ilerleme basamakları olarak tanımlanabilir (Şimşe ve diğ., 2004:15). Çeşitli kariyer aşamalarının temel önermesi şudur; insanlar kariyerleri süresince göze çarpan meslek aşamaları boyunca ilerler. Her bir aşamada çalışanların işteki tutum ve davranışları farklı olarak tanımlanır (Oplatka, 2010:779).

İşe alışların ilk aşamasında personele çırak gözü ile bakılır. Oryantasyon ve sosyal aktiviteler örgüt tarafından önemlidir. Bunlar yeni personelin bir an önce yeni mesleklerine ve iş arkadaşlarına alışmasını kolaylaştırır. Böylece onlar da şirketin hedeflerine iştirak etmiş olurlar (Noe, 1999:336). Kariyer seçimi yapan kişi, seçimin iş performansından meydana gelen memnuniyet vasıtasıyla yapılacağını umar (Bland, 1986:15). Doğru meslek tercihinin çoğunlukla bireyin kişisel özellikleri ile ilgili olduğu iddia edilse de bu konuda bireyin doğru seçim yapmasını engelleyen pek çok sübjektif faktör (aile, arkadaş vb. çevre baskısı, mesleğe biçilen toplumsal değer, mesleğin ekonomik itibarı) mevcuttur (Ergün, 2007:22).

Drucker ilk iş seçiminin kişinin kendisi tarafından yapılmasının doğru ve sağlıklı bir karar olacağını belirtmektedir. Çünkü birey ilgi, yetenek, deneyim, gereksinim ve nitelikleri doğrultusunda bir iş seçimi yaparsa, seçim yaptığı işle kendisi arasındaki uyumu sağlamış olacaktır (Uygur, 1998:18).

Umut kısmen; hedef ile ilişkili başarı algısı olarak tanımlanır (Hammond ve diğ., 2009:42). Umutsuzluk, umudun tamamlayıcısı veya tersidir (Ferdico, 1999: 24). Miller umut kavramını, duygu, beklenti, istek olarak tanımlamakta ve umudun yasamın içgüdüsel bir öğesi olduğunu bireyleri incitmekten koruyarak potansiyellerini kolaylaştırdığını ifade etmektedir (Yıldız, 2009:40). Kötümser kişilik tarzı da umutsuzluğun nedenleri arasındadır (Ciarrochi ve Heaven, 2008:1279). 
Umutsuzluğun temeli, geçmişte yaşanmış olumsuz bir olaya dayanır. Bireyler meydana gelen olayların neticesinde ortaya çıkacak olumsuz sonuçların kendilerine etkileri hakkında mütalaalarda bulunurlar ve neticede umutsuzluk ortaya çıkar. Bu doğrultuda umutsuzluk başarısızlığın sonucunda alınmış mağlubiyeti ve teslimiyeti, geleceğe olan inancın yitirilmesini ifade eder (Ottekin, 2009:33).

Son olarak yılmazlık ile ilgili literatür incelendiğinde, yılmazlık ile ilgili oldukça çeşitli ve belirsiz terimlerin kullanıldığı görülmektedir. Yılmazlığın çok sayıda tanımı vardır. Bu konuya değinen pek çok yol ve çok çeşitli kavramlar bulunmaktadır. Bu kavramların birbirinden farklı olduğu sanılır ancak; birbirleriyle açıkça ilgilidir (Mccoy, 2010:3). Geçmişte araştırmacılar, özellikle çocukluk döneminde stresli ve travmatik deneyimlerden sonra negatif sonuçlara odaklanmışlardır (Coulson, 2006:4). Yılmazlığın tanımında, teorik araştırmalarda fikir birliği oranı oldukça düşüktür.

Yılmazlık, teorik çalışmalarda değişik şekillerde tanımlanmıştır (Gardynik, 2008:2). Yılmazlık temelde, olumsuz durumlara maruz kalan bireyleri veya grupları karakterize eden bir dönemdir (LaHousse, 2005:7). Yüksek riskli gençlerin (ergen) yılmazlık durumları araştırmaların odak noktası olmuştur (Braccio, 2009:47).

Yılmazlıkla ilgili ilk çalışmalar ciddi zihinsel rahatsızlığı olan hastaların, uyumsuzluklarını anlamak ve problemlerin ortaya çıkış nedenleri ile bu hastalıkların oluşmasına uygun zemin hazırladığı düşünülen risk faktörlerini bulmak amacıyla yapılmıştır (Gürgân, 2006:11). Yılmazlık kavramının tanımlanması konusunda tam bir uzlaşma olmasa da, aşağıdaki sunulan tanımlar kavramın tam olarak anlaşılmasına katkı sağlayabilir. Yılmazlık kavramı; Latince "resiliens" (yılmaz/sağlam) kökünden türemiştir ve bir maddenin elastik olması ve aslına kolayca dönebilmesini ifade etmektedir. Webster Yeni Yirminci Yüzyıl İngilizce Sözlüğü'ne göre yılmazlık "sıkıştırıldıktan sonra eski haline gelmek/dönmek ve güç, enerji, cesaret kazanmak" anlamına gelmektedir. Gürgân'ın yapmış olduğu çalışmasında yılmazlık; "sıkıştırılıp ya da esnetildikten sonra orijinal formuna ya da pozisyonuna dönebilme becerisi", "değişim, hastalık ve kötü kaderden hızlıca kurtulma, "iyileşme dirençlilik, çabuk iyileşme gücü, zorlukları yenme gücü, esneklik" olarak tanımlanmaktadır (Gürgân, 2006:13). Yılmazlık, bireyleri zorluklara ve güçlüklere adapte eden tutum ve beceriler olarak da tanımlanabilmektedir (Bulthuis, 2008:3).

\section{Konuya İlişkin Yapılan Çalışmalar}

Yapılan bu çalışma ile ilgili birebir benzer bir çalışma bulunmamakla beraber umutsuzluk, kariyer seçimi ve yılmazlık konusunda çeşitli çalışmalar yapılmıştır. Bu çalışmalardan bazıları aşağıda özetlenmiştir;

Duman ve arkadaşlarının (2009), Beden Eğitimi ve Spor Yüksekokulu Spor Yöneticiliği Bölümünde okuyan Öğrencilerin Umutsuzluk Düzeylerinin İncelenmesi adlı makale çalışmaları neticesinde, erkek öğrencilerin umutsuzluk durumu kız öğrencilere göre daha fazladır. Dördüncü sınıf öğrencilerinin gelecekle ilgili umutsuz duygu düzeyleri birinci sınıf öğrencilerinden anlamlı düzeyde yüksek bulunurken; birinci sınıf ve dördüncü sınıf öğrencilerinin umutsuzluk motivasyon kaybı, gelecekle ilgili olumsuz beklenti ve toplam umutsuzluk puan ortalamaları arasında anlamlı bir farklılaşmanın olmadığı görülmüştür.

Özmen vd (2008)'nin, Lise Öğrencilerinde Umutsuzluk ve Umutsuzluk Düzeyini Etkileyen Etkenler adlı çalışmaları neticesinde, Erkek öğrencilerin umutsuzluk puanı kız öğrencilere oranla daha yüksek olduğu saptanmıştır. Lise 1. Sınıfta okuyan 
öğrencilerin gelecekten genel olarak umutlu olduklarını, fakat umutsuz olanların oranlarının da az olmadığını ve sosyoekonomik olarak daha düşük düzeyde olan ailelerin çocuklarının daha umutsuz olduğu görülmektedir.

Tekin ve filiz (2008)'in, Beden Eğitimi ve Spor Yüksekokullarının Antrenörlük Eğitimi ve Spor Yöneticiliği Bölümlerinde Öğrenim Gören Öğrencilerin Umutsuzluk ve Boyun Eğici Davranış Düzeylerinin Çeşitli Değişkenlere Göre İncelenmesi adlı çalışmalarının neticesinde beden eğitimi ve spor yüksekokulunda antrenörlük eğitimi ve spor yöneticiliği bölümünde öğrenim gören öğrencilerin umutsuzluk düzeyleri ile boyun eğici davranış düzeyleri arasında pozitif ve anlamlı bir ilişkinin olduğu görülmüştür.

Ross'un (1992) çalışmasına göre turizm sektöründe doğrudan deneyim sahibi olmanın öğrencileri sektörle ilgili olumlu tutumlara götürdüğü belirtilmektedir. Joiner ve

arkadaşları (2005), 169 üniversite öğrencisi üzerinde gerçekleştirdikleri araştırmalarının neticesinde, umutsuzluğun depresif semptomlarda artışa neden olduğunu bildirmişlerdir. Shiomi (1995), Japonya'da öğrenciler üzerinde yaptığı çalışma sonucunda, umutsuzluğun okul aktivitelerini olumsuz etkilediğini belirtmiştir. Boella (2000)'in çalışmasına göre turizm sektörünün saygınlığı düşük olarak görülmektedir. Bu nedenle kariyer yapma konusunu olumsuz etkilemektedir.

Lustig ve Strauser (2002), kolej öğrencisinin tutarlılık hissinin kariyer düşünce süreçlerine etkisini araştırmışlardır. Araştırma sonuçlarına göre kariyer kararı verme süreci ile daha etkili biçimde başa çıkabildiklerine ilişkin hipotezi desteklemiştir. Lyon ve Doll (1998)'un yılmazlık ile ilgili yapmış oldukları çalışmaya göre; risk ve yılmazlık çalışmaları son kırk yıldır devam etmektedir. İlk kuşak risk faktörlerinin sistematik araştırmalarıyla ve bu faktörlerin dezavantajlı çocuklar arasındaki uyumsuzluğun bütün çeşitleriyle olan ilgileri üzerinde durmuşlardır.

\section{Araştırmanın Yöntemi}

$\mathrm{Bu}$ araştırma, üniversitede turizm eğitimi alan öğrencilerin umutsuzluk, yılmazlık durumları ve sektörel tutumlarının kariyer seçimlerine etkilerini belirlemek amacıyla yapılmıştır. Çalışma, öğrencilerin kariyerlerine ilişkin mevcut tutumlarını ve geleceğe ilişkin beklentilerini ortaya koyması bakımından önem taşımaktadır.

Yapılan araştırmada aşağıdaki 3 soruya cevap aranmıştır;

1. Öğrencilerin umutsuzluk durumlarının kariyer seçimleriyle ilişkisi var mıdır?

2. Öğrencilerin yılmazlık durumlarının kariyer seçimleriyle ilişkisi var mıdır?

3. Öğrencilerin sektörel tutumlarının kariyer seçimleriyle ilişkisi var mıdır?

Araştırmada bu sorular doğrultusunda ilk olarak literatür incelemesi yapılmış ve buradan elde edilen kuramsal bilgiler ışığında ikincil verilerin analizi gerçekleştirilmiştir. Elde edilen bilgilere dayanarak, alan araştırması kapsamında anket tekniği kullanılmıştır. Kullanılan anket dört bölümden oluşmaktadır: ilk bölümde Duman ve diğ. (2006) tarafından oluşturulan 29 madde sektörel tutuma yönelik, 10 madde kariyer seçimine yönelik 39 maddeden oluşan ölçek, ikinci bölümde Seber (1991) tarafından çevirisi yapılan 20 maddelik Beck Umutsuzluk Ölçeği (BUÖ), üçüncü bölümde Gürgan (2006) tarafından geliştirilen 50 maddelik Yılmazlık Ölçeği ve demografik bilgilere ilişkin sorular yer almaktadır. Elde edilen verilere, istatistik paket programı ile normal dağılım testi, güvenirlik ve faktör analizleri yapılmış ve bu faktörler üzerinden korelasyon ve regresyon analizleri gerçekleştirilmiştir. Ölçeklerin güvenirlik katsayıları sırasıyla; Kariyer Seçimi Ölçeği güvenirlik katsayısı (Cronbach Alpha) 0,848, Umutsuzluk Ölçeğinin güvenirlik katsayısı (Cronbach Alpha) 0,612, Yılmazlık Ölçeği güvenirlik 
katsayısı (Cronbach Alpha) 0,934, Sektörel tutum ölçeğinin güvenirlik katsayısı ise 0,820 (Cronbach Alpha) olarak bulunmuştur. Çalışmanın örneklemini Akdeniz Üniversitesi Turizm İşletmeciliği ve Otelcilik Yüksekokulu'nda lisans eğitimi alan 816 öğrenci oluşturmaktadır. Toplam 370 öğrenciye ulaşılmış ve 336 adet anket analize alınmıştır.

\section{Bulgular}

Tablo 1'e göre; araştırmaya katılan öğrencilerin \%40,5'i erkek öğrencilerden, $\% 59,5$ 'i kız öğrencilerden oluşmaktadır. Araştırmaya katılanların \%62,4'ünün 17-21 yaş arası, \%37,6'sının ise 22 yaş ve üzeri olduğu görülmektedir. Çalışmada yer alan öğrencilerin \%42,6'sı Seyahat İşletmeciliği bölümünde, \%51,8'i Konaklama İşletmeciliği bölümünde, \%5,7'si Yiyecek-İcecek işletmeciliği bölümünde eğitim görmektedir. Araştırmaya katılan öğrencilerin \%28,6' sı birinci sınıf, \%24,1'i ikinci sınıf, \%28,6'sı üçüncü sınıf ve \%18,8'i dördüncü sınıfta okuyan öğrenciler oluşturmaktadır. Araştırmaya katılan öğrencilerin mezun oldukları lise ile ilgili bilgilerine ilişkin elde edilen bulgular incelendiğinde; öğrencilerin \%55,7'lik bir bölümünün Turizm ile ilgili bir lise mezunu, \%21,7'si genel lise mezunu, \%22,6's। ise diğer liselerden mezun olduklarını belirtmiştir. Bu rakamsal bulgularla ilgili tablo aşağıda yer almaktadır (Tablo 1).

Tablo 1: Araştırmaya Katılanlarla İlgili Bazı Tanıtıcı Bilgiler

\begin{tabular}{|l|l|l|l|l|l|}
\hline Cinsiyet & $\mathbf{N}$ & $\%$ & Sınıf & $\mathbf{n}$ & $\%$ \\
\hline Kız & 136 & 40,5 & 1. Sınıf & 96 & 34,7 \\
\hline Erkek & 200 & 59,5 & 2. Sınıf & 81 & 25,5 \\
\hline Yaş & $\mathbf{N}$ & $\%$ & 3. Sınıf & 96 & 20,5 \\
\hline 17-21 yaş & 210 & 62,4 & 4. Sınıf & 63 & 15,6 \\
\hline 22ve üzeri & 126 & 37,6 & & & \\
\hline Mezun Olunan Lise & $\mathbf{N}$ & $\%$ & Eğitim Alınan Bölüm & $\mathbf{n}$ & $\%$ \\
\hline Turizm Eğitimi Veren Liseler & 187 & 55,7 & Seyahat İşletmeciliği & 143 & 42,6 \\
\hline Genel Lise & 73 & 21,7 & Konaklama İşletmeciliği & 174 & 51,8 \\
\hline Diğer & 76 & 22,6 & Yiyecek- İçecek İşletmeciliği & 19 & 5,7 \\
\hline
\end{tabular}

Sektörel tutum ölçeğine yönelik faktör analizi öncesinde 39 maddeden oluşan ölçeğin faktör analizine uygunluğu kontrol edilmiştir. Kaiser-Meyer-Olkin örneklem yeterliliği 0,797 olarak bulunmuştur. Bu değer verinin faktör analizine uygun olduğunu göstermektedir. Toplanan verilere temel bileşenler yöntemi ile faktör analizi yapılmıştır. Yapılan ilk faktör analizinde 11 boyut elde edilmiştir. Bu boyutlar içinde yer alan değişkenlerden güvenilirliği düşüren ve düşük yükleme değerine sahip $(<, 40)$ ve/veya çapraz yüklenen 18 madde bir sonraki faktör analizine dâhil edilmemiştir. Geri kalan 21 değişken ile yapılan faktör analizinde elde edilen boyutlara uygulanan güvenilirlik analizi sonucunda, güvenilirlik katsayısı (Cronbach Alpha) 0,820 olarak bulunmuştur. Böylece özdeğeri 1'den büyük ve faktör yükü 0.40 'ın üzerinde olan toplam 6 faktör elde edilmiştir. Elde edilen 6 faktör toplam varyansın \%56.32'sini açıklamaktadır. Faktörlerin Cronbach Alpha ile hesaplanan güvenilirlik katsayıları 0,59 ile 0,733 arasındadır. Faktörlerde herhangi bir madde çıkarıldığında güvenilirlik katsayısı artmadığından, faktörleri oluşturan tüm maddeler bundan sonraki analizlere dâhil edilmiştir. 
Tablo 2: Sektörel Tutum Ölçeği Faktör Analizi

\begin{tabular}{|c|c|c|c|c|}
\hline Faktörler & 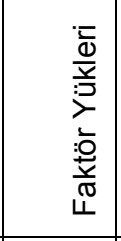 & 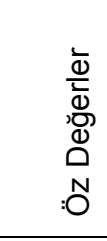 & 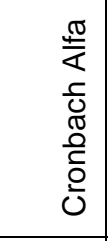 & 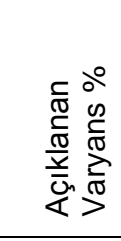 \\
\hline Faktör 1: İş Ortamı & & 4,721 & 0,73 & 22,481 \\
\hline Turizm endüstrisinde çalışma saatleri düzensizdir & 0,786 & & & \\
\hline Turizm sektöründe çalışma saatleri çok uzundur & 0,771 & & & \\
\hline Turizm sektöründeki çalışma ortamı streslidir & 0,632 & & & \\
\hline $\begin{array}{l}\text { Mevsimsellik özelliğinden dolayı turizm sektöründe daimi bir iş } \\
\text { bulmak zordur }\end{array}$ & 0,570 & & & \\
\hline Turizm endüstrisindeki işler çok yorucudur & 0,495 & & & \\
\hline Faktör 2: Sektörel Kariyer ve Saygınlık & & 1,901 & 0,60 & 9,053 \\
\hline Bu sektörde çok para kazanabileceğimi düşünmüyorum & 0,659 & & & \\
\hline $\begin{array}{l}\text { Bazen çevreme turizm endüstrisinde kariyer yapacağımı } \\
\text { söylemeye çekiniyorum }\end{array}$ & 0,658 & & & \\
\hline $\begin{array}{l}\text { Turizm sektöründe çalışmak ahlaki değerlerden ödün vermeyi } \\
\text { gerektirir }\end{array}$ & 0,619 & & & \\
\hline Turizm sektöründe çalışmak toplumda fazla saygı görmüyor & 0,556 & & & \\
\hline Faktör 3: Ücret Sistemi & & 1,622 & 0,72 & 7,726 \\
\hline Turizm sektöründeki birçok işin ücreti düşüktür & 0,800 & & & \\
\hline $\begin{array}{l}\text { Sektör dışındaki ek gelirler (prim, konaklama, ulaşım, ikramiye) } \\
\text { yetersizdir }\end{array}$ & 0,785 & & & \\
\hline $\begin{array}{l}\text { Bu sektörde birçok işin ücreti ekonomik olarak rahat bir hayat } \\
\text { sürmek için yetersizdir }\end{array}$ & 0,576 & & & \\
\hline Faktör 4: Eğitim ve Sektörel Uyum & & 1,287 & 0,64 & 6,129 \\
\hline $\begin{array}{l}\text { Turizm sektöründe çalışanların genelde eğitim seviyeleri } \\
\text { düşüktür }\end{array}$ & 0,748 & & & \\
\hline $\begin{array}{l}\text { Yöneticiler çalışanların işletmeye olan bağlılıklarını arttırmak } \\
\text { için yeterli çaba göstermez }\end{array}$ & 0,665 & & & \\
\hline Turizm sektörü çalışanlarında ekip ruhu gelişmemiştir & 0,645 & & & \\
\hline $\begin{array}{lllll}\text { Sektörde çalışan yöneticilerin } & \text { birçoğu } & \text { turizm } & \text { eğitimi } \\
\text { almamışlardır } & & & \\
\end{array}$ & 0,500 & & & \\
\hline Faktör 5: Terfi & & 1,238 & 0,59 & 5,855 \\
\hline Sektörde terfi imkânları kısıtlıdır & 0,722 & & & \\
\hline Sektörde tanıdığı (torpili) olmayanın terfi etmesi zordur & 0,684 & & & \\
\hline $\begin{array}{l}\text { Turizm işletmelerinde terfi kararları alınırken çalışanların eğitim } \\
\text { düzeyi dikkate alınmaz }\end{array}$ & 0,626 & & & \\
\hline Faktör 6: Sosyal Beklenti & & 1,057 & 0,68 & 5,032 \\
\hline Hafta sonu tatili benim için çok önemlidir & 0,807 & & & \\
\hline Özel hayatim benim için çok önemlidir & 0,783 & & & \\
\hline Toplam Açıklanan Varyans & 56,315 & & & \\
\hline Cronbach Alpha & 0,820 & & & \\
\hline KMO Test & 0,797 & & & \\
\hline Bartlett's Test of Sphericity & X2: 162 & 4,831 & ig 0,00 & \\
\hline
\end{tabular}

Yılmazlık ölçeğine yönelik faktör analizi öncesinde 50 maddeden oluşan ölçeğin faktör analizine uygunluğu kontrol edilmiştir. Kaiser-Meyer-Olkin örneklem yeterliliği 0,936 olarak bulunmuştur. Bu değer verinin faktör analizine uygun olduğunu göstermektedir. Toplanan verilere temel bileşenler yöntemi ile faktör analizi yapılmıştır. Yapılan ilk faktör analizinde 11 boyut elde edilmiştir. Bu boyutlar içinde yer alan değişkenlerden güvenilirliği düşüren ve düşük yükleme değerine 
sahip (<.40) ve/veya çapraz yüklenen 24 madde bir sonraki faktör analizine dâhil edilmemiştir. Geri kalan 26 değişken ile yapılan faktör analizinde elde edilen boyutlara uygulanan güvenilirlik analizi sonucunda, güvenilirlik katsayısı (Cronbach Alpha) 0,934 olarak bulunmuştur. Böylece özdeğeri1'den büyük ve faktör yükü 0.40 'ın üzerinde olan toplam 4 faktör elde edilmiştir. Elde edilen 4 faktör toplam varyansın \%52,577'ini açıklamaktadır. Faktörlerin Cronbach Alpha ile hesaplanan güvenilirlik katsayıları 0,738 ile 0,873 arasındadır. Faktörlerde herhangi bir madde çıkarıldığında güvenilirlik katsayısı artmadığından, faktörleri oluşturan tüm maddeler bundan sonraki analizlere dâhil edilmiştir. Bartlett testi sonucunda elde edilen 0,001 değeri $(p<0,05)$ verilerin anlamlı dağıldığına işaret etmektedir.

Tablo 3: Yılmazlık Ölçeği Faktör Analizi

\begin{tabular}{|c|c|c|c|c|}
\hline Faktörler & 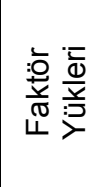 & 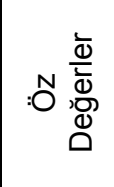 & 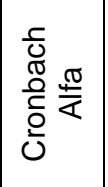 & 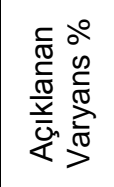 \\
\hline Faktör 1: Güçlü Olma & & 9,899 & 0,873 & 38,073 \\
\hline İnandığım şeyler için sonuna kadar mücadele ederim & 0,732 & & & \\
\hline $\begin{array}{l}\text { Başkalarının üstesinden gelemeyeceği olumsuz yaşam koşulları } \\
\text { ile baş etmeyi bilirim }\end{array}$ & 0,659 & & & \\
\hline Kendime her zaman güvenirim & 0,572 & & & \\
\hline Parlak bir geleceğe sahip olma duygusu ve umudu içindeyim & 0,560 & & & \\
\hline Sözlü ve yazılı olarak kendimi ifade etmeyi başarırım & 0,540 & & & \\
\hline İçinde yer aldığım gruplarda etkin rol oynarım & 0,525 & & & \\
\hline En zor şartlarda bile kendi kendimi iyileştirme yetisine sahibim & 0,503 & & & \\
\hline $\begin{array}{l}\text { Çevremdekiler üzerinde olumlu izlenimler bırakarak onların } \\
\text { güvenini kazanırım }\end{array}$ & 0,488 & & & \\
\hline Güçlükler karsısında yılmadan, sabırla mücadele ederim & 0,481 & & & \\
\hline Diğer insanlardan gelen sinyalleri iyi okurum & 0,462 & & & \\
\hline Dertlerimi unutabilmek için yaratıcılığımı kullanabilirim & 0,427 & & & \\
\hline Faktör 2: İyimser Olma & & 1,336 & 0,817 & 5,137 \\
\hline Kendimle barışığım & 0,727 & & & \\
\hline Genellikle gülecek bir seyler bulabilirim & 0,7 & & & \\
\hline Genellikle bir duruma birçok yönden bakabilirim & 0,575 & & & \\
\hline Planlar yaptığım zaman, onları sonuna kadar götürürüm & 0,519 & & & \\
\hline Hedeflerime ulaşmak için kendimi güdüleyebilirim & 0,497 & & & \\
\hline En zor durumlarda bile kendime inancımı kaybetmem & 0,413 & & & \\
\hline Faktör 3: Lider Olma & & 1,301 & 0,738 & 5,005 \\
\hline Çevremdeki olanak ve fırsatları kolay görüp değerlendiririm & 0,698 & & & \\
\hline Başarı için olabildiğince yüksek ama ulaşılabilir hedeflerim var & 0,665 & & & \\
\hline $\begin{array}{l}\text { Kararlarımın sonuçlarına baktığımda genellikle isabetli kararlar } \\
\text { verdiğimi görürüm }\end{array}$ & 0,603 & & & \\
\hline $\begin{array}{l}\text { Meraklıyım, sorular sorar, bilmediğim şeyleri öğrenmek için } \\
\text { araştıırım }\end{array}$ & 0,602 & & & \\
\hline Faktör 4: Öngörü & & 1,134 & 0,787 & 4,362 \\
\hline Çıkabilecek problemleri önceden kestirerek önlemlerimi alırım & 0,646 & & & \\
\hline Çözüm yollarını hemen görerek uygulamaya koyarım & 0,639 & & & \\
\hline Zor olan durumları bile lehime çevirmekte hünerliyim & 0,621 & & & \\
\hline Kimsenin fark edemediği yaratıcı çözüm yollarını görebilirim & 0,548 & & & \\
\hline $\begin{array}{l}\text { Zor bir durumda kaldığımda genellikle o durumdan çıkış yolunu } \\
\text { bulabilirim }\end{array}$ & 0,526 & & & \\
\hline Toplam Açıklanan Varyans & \multicolumn{4}{|l|}{52,577} \\
\hline Cronbach Alpha & \multicolumn{4}{|l|}{0,934} \\
\hline KMO Test & \multicolumn{4}{|l|}{0,936} \\
\hline Bartlett's Test of Sphericity & \multicolumn{4}{|c|}{ X2: 3750,$046 ;$ Sig:0,001 } \\
\hline
\end{tabular}


Umutsuzluk ölçeğine yönelik faktör analizi öncesinde 20 maddeden oluşan ölçeğin faktör analizine uygunluğu kontrol edilmiştir. Kaiser-Meyer-Olkin örneklem yeterliliği 0,851 olarak bulunmuştur. Bu değer verinin faktör analizine uygun olduğunu göstermektedir. Toplanan verilere temel bileşenler yöntemi ile faktör analizi yapılmıştır. Yapılan ilk faktör analizinde 3 boyut elde edilmiştir. Bu boyutlar içinde yer alan değişkenlerden güvenilirliği düşüren ve düşük yükleme değerine sahip $(<.40)$ ve/veya çapraz yüklenen 8 madde bir sonraki faktör analizine dâhil edilmemiştir. Geri kalan 11 değişken ile yapılan faktör analizinde elde edilen boyutlara uygulanan güvenilirlik analizi sonucunda, güvenilirlik katsayısı (Cronbach Alpha) 0,612 olarak bulunmuştur. Böylece özdeğeri 1 'den büyük ve faktör yükü 0,40 'ın üzerinde olan toplam 3 faktör elde edilmiştir. Elde edilen 3 faktör toplam varyansın \%55,293'ünü açıklamaktadır. Faktörlerin Cronbach Alpha ile hesaplanan güvenilirlik katsayıları 0,655 ile 0,778 arasındadır. Faktörlerde herhangi bir madde çıkarıldığında güvenilirlik katsayısı artmadığından, faktörleri oluşturan tüm maddeler bundan sonraki analizlere dâhil edilmiştir.

Tablo 4: Umutsuzluk Ölçeği Faktör Analizi

\begin{tabular}{|c|c|c|c|c|}
\hline Faktörler & 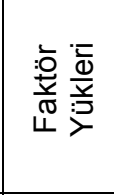 & 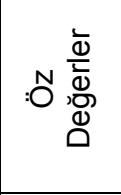 & 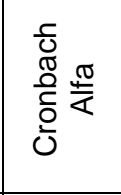 & 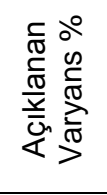 \\
\hline Faktör 1: Motivasyon Kaybı & & 4,161 & 0,778 & 34,677 \\
\hline Gelecekte gerçek doyuma ulaşmam imkânsız gibi & 0,77 & & & \\
\hline $\begin{array}{l}\text { İyi fırsatlar yakalayamıyorum, gelecekte yakalayacağıma } \\
\text { inanmam için de hiçbir neden yok }\end{array}$ & 0,756 & & & \\
\hline $\begin{array}{l}\text { Kendimle ilgili şeyleri düzeltemediğime göre çabalamayı } \\
\text { bıraksam iyi olur }\end{array}$ & 0,674 & & & \\
\hline Geleceğimi karanlık görüyorum & 0,544 & & & \\
\hline $\begin{array}{l}\text { Arzu ettiğim şeyleri elde edemediğime göre bir şeyler istemek } \\
\text { aptallık olur }\end{array}$ & 0,542 & & & \\
\hline Gelecek bana bulanık ve belirsiz görünüyor & 0,497 & & & \\
\hline Faktör 2: Umut & & 1,322 & 0,655 & 11,015 \\
\hline Gerçekten özlediğim şeylere kavuşabileceğimi umuyorum & 0,773 & & & \\
\hline $\begin{array}{l}\text { Geleceğe baktığımda şimdikine oranla daha mutlu olacağımı } \\
\text { umuyorum }\end{array}$ & 0,742 & & & \\
\hline $\begin{array}{l}\text { İşler kötüye giderken bile her şeyin böyle kalmayacağını } \\
\text { bilmek rahatlatıyor }\end{array}$ & 0,706 & & & \\
\hline Faktör 3: Gelecek İle İlgili Beklentiler & & 1,152 & 0,686 & 9,601 \\
\hline $\begin{array}{l}\text { Yapmayı en çok istediğim şeyleri gerçekleştirmek için yeterli } \\
\text { zamanım var }\end{array}$ & 0,773 & & & \\
\hline Geleceğe umut ve coşku ile bakıyorum & 0,734 & & & \\
\hline Geçmiş deneyimlerim beni geleceğe iyi hazırladı & 0,723 & & & \\
\hline Toplam Açıklanan Varyans & 55,293 & & & \\
\hline Cronbach Alpha & 0,612 & & & \\
\hline KMO Test & 0,851 & & & \\
\hline Bartlett's Test of Sphericity & & & & \\
\hline
\end{tabular}

Kariyer seçimi ölçeğine yönelik faktör analizi öncesinde 10 maddeden oluşan ölçeğin faktör analizine uygunluğu kontrol edilmiştir. Kaiser-Meyer-Olkin örneklem yeterliliği 0,817 olarak bulunmuştur. Bu değer verinin faktör analizine uygun olduğunu göstermektedir. Toplanan verilere temel bileşenler yöntemi ile faktör analizi yapılmıştır. Yapılan ilk faktör analizinde 2 boyut elde edilmiştir. Bu boyutlar içinde yer alan değişkenlerden güvenilirliği düşüren ve düşük yükleme değerine 
sahip (<.40) ve/veya çapraz yüklenen 5 madde bir sonraki faktör analizine dâhil edilmemiştir. Geri kalan 5 değişken ile yapılan faktör analizinde elde edilen boyutlara uygulanan güvenilirlik analizi sonucunda, güvenilirlik katsayısı (Cronbach Alpha) 0,848 olarak bulunmuştur. Böylece özdeğeri 1'den büyük ve faktör yükü 0,40 'ın üzerinde olan tek 1 faktör elde edilmiştir. Elde edilen faktör toplam varyansın \%62,460'ını açıklamaktadır.

Tablo 5: Kariyer Seçimi Ölçeği Faktör Analizi

\begin{tabular}{|c|c|c|c|c|}
\hline Faktörler & 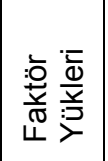 & 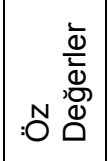 & 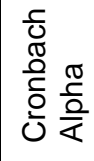 & 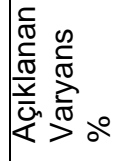 \\
\hline Faktör 1: Kariyer Seçimi & & 3,123 & 0,848 & 62,460 \\
\hline $\begin{array}{l}\text { Turizm endüstrisinde kariyer yapmamın bana kazandıracağı fazla } \\
\text { bir şey yok }\end{array}$ & 0,823 & & & \\
\hline Bu mesleği seçmem benim için bir hataydı & 0,820 & & & \\
\hline Mezun olunca turizm sektöründe çalışacağımı sanmıyorum & 0,807 & & & \\
\hline Bu sektörde uzun yıllar çalışamam & 0,783 & & & \\
\hline Okuldan mezun olunca ne iş yapacağımı bilmiyorum & 0,713 & & & \\
\hline Toplam Açıklanan Varyans & \multicolumn{4}{|l|}{62,460} \\
\hline Cronbach Alpha & \multicolumn{4}{|l|}{0,848} \\
\hline KMO Test & \multicolumn{4}{|c|}{0,817} \\
\hline Bartlett's Test of Sphericity & \multicolumn{4}{|c|}{ X2: 706,640; Sig:0,001 } \\
\hline
\end{tabular}

Değişkenler arasındaki ilişkiler korelasyon analizi ile incelenmiştir (Tablo 7). Bazı değişkenler arasında $p<0,01$ ve $p<0,05$ anlam düzeylerinde çift ve/veya tek yönlü pozitif ilişkiler olduğu, bazı değişkenler arasında ise istatistiksel olarak anlamlı ilişki olmadığı $(p>0,05)$ belirlenmiştir. Araştırma hipotezlerinin test sonuçları aşağıda yer almaktadır.

$\mathrm{H}_{1}$ : Turizm eğitimi alan öğrencilerin kariyer seçimi ile sektörel tutum faktörlerinden iş ortamı arasında ilişki vardır.

Korelasyon analizi sonuçlarına göre kariyer seçimi ile sektörel tutum faktörlerinden "iş ortamı" arasında 0,01 anlamlılık düzeyinde pozitif yönlü zayıf bir ilişki $(r=0,210)$ bulunmuştur. $\mathrm{H}_{1}$ hipotezi kabul edilmiştir.

$\mathrm{H}_{2}$ : Turizm eğitimi alan öğrencilerin kariyer seçimi ile sektörel tutum faktörlerinden sektörel kariyer ve saygınlık arasında ilişki vardır

Korelasyon analizi sonuçlarına göre kariyer seçimi ile sektörel tutum faktörlerinden "sektörel kariyer ve saygınlık" arasında 0,01 anlamlılık düzeyinde pozitif yönlü bir ilişki $(r=0,611)$ bulunmuştur. $\mathrm{H}_{2}$ hipotezi kabul edilmiştir.

$\mathrm{H}_{3}$ : Turizm eğitimi alan öğrencilerin kariyer seçimi ile sektörel tutum faktörlerinden ücret sistemi arasında ilişki vardır.

Değişkenler arasındaki ilişkiye yönelik korelasyon analizi sonuçlarına göre kariyer seçimi ile sektörel tutum faktörlerinden ücret sistemi arasında 0,01 anlamlılık düzeyinde pozitif yönlü zayıf bir ilişki $(r=0,267)$ bulunmuştur. $\mathrm{H}_{3}$ hipotezi kabul edilmiştir.

$\mathrm{H}_{4}$ : Turizm eğitimi alan öğrencilerin kariyer seçimi ile sektörel tutum faktörlerinden eğitim ve sektörel uyum arasında ilişki vardır

Değişkenler arasındaki ilişkiye yönelik korelasyon analizi sonuçlarına göre kariyer seçimi ile sektörel tutum faktörlerinden eğitim ve sektörel uyum arasında 0,01 
anlamlılık düzeyinde pozitif yönlü zayıf bir ilişki $(r=0,239)$ bulunmuştur. $\mathrm{H}_{4}$ hipotezi kabul edilmiştir.

$\mathrm{H}_{5}$ : Turizm eğitimi alan öğrencilerin kariyer seçimi ile sektörel tutum faktörlerinden terfi arasında ilişki vardır

Değişkenler arasındaki ilişkiye yönelik korelasyon analizi sonuçlarına göre kariyer seçimi ile sektörel tutum faktörlerinden terfi arasında 0,01 anlamlılık düzeyinde pozitif yönlü zayıf bir ilişki $(r=0,336)$ bulunmuştur. $H_{5}$ hipotezi kabul edilmiştir.

$\mathrm{H}_{6}$ : Turizm eğitimi alan öğrencilerin kariyer seçimi ile sektörel tutum faktörlerinden sosyal beklenti arasında ilişki vardır

Değişkenler arasındaki ilişkiye yönelik korelasyon analizi sonuçlarına göre kariyer seçimi ile sektörel tutum faktörlerinden sosyal beklenti arasında 0,01 anlamlılık düzeyinde pozitif yönlü zayıf bir ilişki $(r=0,186)$ bulunmuştur. $H_{6}$ hipotezi kabul edilmiştir.

Tablo 6: Kariyer Seçimi ve Sektörel Tutum Ölçeği İle İlgili Korelasyon Analizi Sonuçları

\begin{tabular}{|c|c|c|c|c|c|c|}
\hline & 1 & 2 & 3 & 4 & 5 & 6 \\
\hline 1. Kariyer Seçimi & 1 & & & & & \\
\hline 2. İş Ortamı & $210^{\star *}$ & 1 & & & & \\
\hline 3.Sektörel Kariyer ve Saygınlık & $611^{* *}$ & $233^{* *}$ & 1 & & & \\
\hline 4. Ücret Sistemi & $267^{\star \star}$ &, $362^{\star \star}$ &, $387^{\star *}$ & 1 & & \\
\hline 5. Eğitim ve Sektörel Uyum &, $239^{\star *}$ & $286^{\star \star}$ &, $260^{\star *}$ & $254^{\star \star}$ & 1 & \\
\hline 6. Terfi & $336^{* *}$ & $265^{\star \star}$ &, $325^{\star *}$ & $368^{* *}$ & $361^{* *}$ & 1 \\
\hline 7. Sosyyal Beklenti & $186^{\star \star}$ & $389^{* *}$ &, $154^{\star \star}$ & $255^{\star \star}$ &, $119^{*}$ & ,239*^ \\
\hline
\end{tabular}

Değişkenler arasındaki ilişkiye yönelik korelasyon analizi sonuçlarına göre (Tablo 7), turizm eğitimi alan öğrencilerin sektörel tutumlarının kariyer seçimlerine etkisini belirlemek için regresyon analizi yapılmıştır. Modelin istatistiksel olarak anlamlı olup olmadığını belirlemeye yönelik anova analizi sonucunda F değeri 36,761 olarak hesaplanmış ve bu değer istatistiksel olarak anlamlı bulunmuştur. Analize ilişkin $\mathrm{R}^{2}$ değeri 0,401 olarak bulunmuştur. Tablo 7'de araştırmada yer alan bağımsız değişkenin standart Beta katsayısı ile $t$ ve $p$ değerleri verilmiştir. Tablo 7 incelendiğinde, öğrencilerin turizm sektörüne yönelik kariyer seçimlerinde en etkili faktörün "sektörel kariyer ve saygınlık" olduğu görülmektedir. Kariyer seçimlerinde diğer etkili faktör ise "terfi"dir. "İ̧̧ ortamı", "ücret sistemi" ve "eğitim ve sektörel uyum" ve "sosyal beklenti" boyutları ise, sektörde kariyer yapma isteğini açıklamada sınırlı bir etkiye sahiptir.

Tablo 7: Kariyer Seçimi ve Sektörel Tutum Ölçeği İle İlgili Regresyon Analizi Sonuçları

\begin{tabular}{|c|c|c|c|c|}
\hline Bağımlı Değişken & Bağımsız Değişkenler & $\begin{array}{l}\text { Beta } \\
\text { Değeri }\end{array}$ & $\begin{array}{l}\mathbf{t} \\
\text { Değeri }\end{array}$ & $\begin{array}{l}\mathbf{p} \\
\text { Değeri }\end{array}$ \\
\hline \multirow{6}{*}{ Kariyer Seçimi } & İş Ortamı & 020 & 398 & 691 \\
\hline & Sektörel Kariyer ve Saygınlık &, 555 & 11,609 &, $000^{*}$ \\
\hline & Ücret Sistemi &,- 031 &,- 616 & ,538 \\
\hline & Eğitim ve Sektörel Uyum & 042 & ,879 & 380 \\
\hline & Terfi &, 132 & 2,670 &, $008^{*}$ \\
\hline & Sosyal Beklenti & 064 & 1,366 &, 173 \\
\hline
\end{tabular}

$\mathrm{H}_{7}$ : Turizm eğitimi alan öğrencilerin kariyer seçimi ile yılmazlık faktörlerinden güçlü olma arasında ilişki vardır. 
Değişkenler arasındaki ilişkiye yönelik korelasyon analizi sonuçlarına göre (Tablo 8) kariyer seçimi ile yılmazlık ölçeği faktörlerinden güçlü olma arasında 0,01 anlamlılık düzeyinde negatif yönlü zayıf bir ilişki $(r=-0,173)$ bulunmuştur. $H_{7}$ hipotezi kabul edilmiştir.

$\mathrm{H}_{8}$ : Turizm eğitimi alan öğrencilerin kariyer seçimi ile yılmazlık faktörlerinden iyimser olma arasında ilişki vardır

Değişkenler arasındaki ilişkiye yönelik korelasyon analizi sonuçlarına göre kariyer seçimi ile yılmazlık ölçeği faktörlerinden iyimser olma arasında 0,01 anlamlılık düzeyinde negatif yönlü zayıf bir ilişki $(r=-0,197)$ bulunmuştur. $H_{8}$ hipotezi kabul edilmiştir.

$\mathrm{H}_{9}$ : Turizm eğitimi alan öğrencilerin kariyer seçimi ile yılmazlık faktörlerinden lider olma arasında ilişki vardır.

Değişkenler arasındaki ilişkiye yönelik korelasyon analizi sonuçlarına göre kariyer seçimi ile yılmazlık ölçeği faktörlerinden lider olma arasında 0,01 anlamlılık düzeyinde negatif yönlü zayıf bir ilişki $(r=-0,232)$ bulunmuştur. $H_{9}$ hipotezi kabul edilmiştir.

$\mathrm{H}_{10}$ : Turizm eğitimi alan öğrencilerin kariyer seçimi ile yılmazlık faktörlerinden öngörü arasında ilişki vardır

Değişkenler arasındaki ilişkiye yönelik korelasyon analizi sonuçlarına göre kariyer seçimi ile yılmazlık ölçeği faktörlerinden öngörü arasında istatistiksel yönden anlamlı bir ilişki tespit edilmemiştir $(p>0,05) . \mathrm{H}_{10}$ hipotezi reddedilmiştir.

Tablo 8: Kariyer Seçimi ve Yılmazlık Ölçeği İle İlgili Korelasyon Analizi Sonuçları

\begin{tabular}{|l|c|c|c|c|c|}
\hline & 1 & 2 & 3 & 4 & 5 \\
\hline 1. Kariyer Seçimi & 1 & & & & \\
\hline 2. Güçlü Olma &,$- 173^{* *}$ & 1 & & & \\
\hline 3. İyimser Olma &,$- 197^{* *}$ &, $758^{* *}$ & 1 & & \\
\hline 4. Lider OIma &,$- 232^{* *}$ &, $626^{* *}$ &, $606^{* *}$ & 1 & \\
\hline 5. Öngörü &,- 087 &, $684^{* *}$ &, $632^{* *}$ &, $552^{* *}$ & 1 \\
\hline
\end{tabular}

Tablo 9'da araştırmada yer alan bağımsız değişkenin standart Beta katsayısı ile t ve $p$ değerleri verilmiştir. Tablo 9incelendiğinde, öğrencilerin turizm sektörünü kariyer olarak seçme isteklerinde, yılmazlık faktörleri arasından en etkili faktörün "lider olma" olduğu görülmüştür. Yılmazlık ölçeğindeki diğer faktörler anlamlı bulunmamıştır.

Tablo 9: Kariyer Seçimi ve Yılmazlık Ölçeği İle İlgili Regresyon Analizi Sonuçları

\begin{tabular}{|c|c|c|c|c|}
\hline Bağımlı Değişken & Bağımsız Değişkenler & Beta Değeri & T Değeri & P Değeri \\
\hline \multirow{3}{*}{$\begin{array}{c}\text { Kariyer } \\
\text { Seçimi }\end{array}$} & Güçlü Olma &,- 039 &,- 422 &, 673 \\
\cline { 2 - 5 } & İyimser Olma &,- 129 & $-1,498$ &, 135 \\
\cline { 2 - 5 } & Lider Olma &,- 204 & $-2,854$ &, $005^{\star}$ \\
\cline { 2 - 5 } & Öngörü & -133 & 1,758 &, 080 \\
\hline
\end{tabular}

$\mathrm{H}_{11}$ : Turizm eğitimi alan öğrencilerin kariyer seçimi ile umutsuzluk ölçeği faktörlerinden umut arasında ilişki vardır.

Değişkenler arasındaki ilişkiye yönelik korelasyon analizi sonuçlarına göre (Tablo 10) kariyer seçimi ile umutsuzluk ölçeği faktörlerinden umut faktörü arasında 0,01 anlamlılık düzeyinde negatif yönlü çok zayıf bir ilişki $(r=-0,135)$ bulunmuştur. $\mathrm{H}_{11}$ hipotezi kabul edilmiştir. 
$\mathrm{H}_{12}$ : Turizm eğitimi alan öğrencilerin kariyer seçimi ile umutsuzluk ölçeği faktörlerinden motivasyon kaybı arasında ilişki vardır.

Değişkenler arasındaki ilişkiye yönelik korelasyon analizi sonuçlarına göre kariyer seçimi ile umutsuzluk ölçeği faktörlerinden motivasyon kaybı arasında istatistiksel yönden anlamlı bir ilişki tespit edilememiştir $(p>0,05) . \quad H_{12}$ hipotezi reddedilmiştir.

$\mathrm{H}_{13}$ : Turizm eğitimi alan öğrencilerin kariyer seçimi ile umutsuzluk ölçeği faktörlerinden gelecek ile ilgili beklentiler arasında ilişki vardır

Değişkenler arasındaki ilişkiye yönelik korelasyon analizi sonuçlarına göre kariyer seçimi ile umutsuzluk ölçeği faktörlerinden gelecek ile ilgili kaygılar arasında istatistiksel yönden anlamlı bir ilişki tespit edilememiştir $(p>0,05) . H_{13}$ hipotezi reddedilmiştir.

Tablo 10: Kariyer Seçimi ve Umutsuzluk Ölçeği İle İlgili Korelasyon Analizi Sonuçları

\begin{tabular}{|l|l|l|l|l|}
\hline & 1 & 2 & 3 & 4 \\
\hline 1. Kariyer Seçimi & 1 & & & \\
\hline 2. Motivasyon Kaybı &,- 065 & 1 & & \\
\hline 3. Gelecekle İlgili Kaygılar & 0,056 &, $373^{\star *}$ & 1 & \\
\hline 4. Umut &, $134^{*}$ &,$- 429^{\star *}$ &,$- 210^{* *}$ & 1 \\
\hline
\end{tabular}

${ }^{*}$ Korelasyon 0.05 düzeyinde çift taraflı öneme sahiptir

** Korelasyon 0.01 düzeyinde çift taraflı öneme sahiptir

Değişkenler arasındaki ilişkiye yönelik korelasyon analizi sonuçlarına göre (Tablo 11) turizm eğitimi alan öğrencilerin umutsuzluk durumlarının kariyer seçimlerine etkisini belirlemek amacıyla regresyon analizi yapılmıştır. Modelin istatistiksel olarak anlamlı olup olmadığını belirlemeye yönelik yapılan anova analizi sonucunda $F$ değeri 3,047 olarak hesaplanmış ve bu değer istatistiksel olarak anlamlı bulunmuştur. Analize ilişkin $\mathrm{R}^{2}$ değeri 0,027 olarak bulunmuştur. Tablo 11 'de araştırmada yer alan bağımsız değişkenin standart Beta katsayısı ile $t$ ve $p$ değerleri verilmiştir. Tablo 11 incelendiğinde, öğrencilerin turizm sektörünü kariyer olarak seçme isteklerinde umutsuzluk faktörleri arasından en etkili faktörün "umut" faktörü olduğu görülmektedir. Diğer faktörler istatistiksel olarak anlamlı bulunmamıştır.

Tablo 11: Kariyer Seçimi ve Umutsuzluk Ölçeği İle İlgili Regresyon Analizi Sonuçları

\begin{tabular}{|l|l|l|l|l|}
\hline Bağımlı Değişken & Bağımsız Değişkenler & Beta Değeri & T Değeri & P Değeri \\
\hline \multirow{3}{*}{ Kariyer } & Motivasyon Kaybı &,- 049 &,- 770 &, 442 \\
\cline { 2 - 5 } Seçimi & Gelecekle İlgili Kaygılar &, 097 & 1,663 &, 096 \\
\cline { 2 - 5 } & Umut &, 135 & 2,245 &, $025^{\star}$ \\
\hline
\end{tabular}

\section{Sonuç}

Yapılan bu çalışmanın sonucunda lisans düzeyinde turizm eğitimi alan öğrencilerin yılmazlık, umutsuzluk ve sektörel tutumlarının kariyer seçimleri üzerindeki etkileri belirlenmiştir. Çalışmanın amacına uygun olarak faktörler arası ilişkinin belirlenebilmesi için korelasyon ve regresyon analizleri yapılmıştır. Öğrencilerin sektöre yönelik tutumları kariyer basamaklarının başlangıcı olan mezuniyet sonrası kariyer tercihleri üzerinde oldukça etkin olduğu görülmüştür. Turizm sektörü emek yoğun ve büyük fedakarılıklar gerektiren bir sektör olarak algılanmaktadır. Dolayısı ile öğrencilerin bu sektöre olan bakış açılarını lisans eğitimi aldıkları sıralarda iyimser bir duruma getirmek için lisans eğitmenlerine ve staj yaptıkları turizm işletmelerine büyük görevler düşmektedir. Öğrencilerin staj dönemlerinde çalışmakta oldukları işletmelerde 
yaşayacakları olumsuz bir durum veya kötü bir sektör deneyimi onları mezuniyet sonrası kariyer seçimlerinde etkileyecektir. Sektör algılarının pozitif yönlü olması turizme yönelik kariyer planlarının da olumlu yönde olmasını sağlamış olacaktır. Bu nedenle sektördeki çalışma koşulları, mesai saatleri, mesleğin saygınlığı, emeklerinin karşılığı olan ücretlerin adil sistemi, sektörel eğitim, terfi ve sosyal beklentileri öğrencilerin kariyere bakış açılarını yönlendirmektedir. Özel sektörde tatil kavramı düzensiz olabilmektedir. Kişilerin çalışma hayatlarının dışına çıkamamaları, sosyal hayatlarının olamayışı onları olumsuz yönde etkileyebilmektedir. Bu nedenle turizm sektörü yöneticileri çalışma yaşamlarının dışında çalışanlara özel hayatlarıyla da ilgilenebilecekleri oranda tatil imkânı tanımalıdırlar. Böylece çalışanların sosyal hayatlarındaki düzen iş yaşamına da yansıyacak ve daha verimli bir işgücü sergilemelerine yardımcı olacaktır. Liyakate dayalı terfilerin olması aynı zamanda işletmeye olan güveni de olumlu yönde etkileyecektir. Kişilerin, sosyal yaşamlarını etkilemeksizin süregelen bir iş yaşamına sahip olmaları sektöre yönelik yapmış oldukları kariyer seçimlerinde elde ettikleri motivasyon neticesinde kariyer basamaklarında emin adımlarla ilerlemelerine yardımcı olacaktır. Bu nedenle işverenler, çalışma şartlarını diğer meslekler gibi kişiyi cezbedebilecek ve kişisel yaşam tatminini sağlayabilecek şekilde düzenlemeler getirdiği takdirde, gerek sektör gerekse sektör çalışanları bu alanda daha da itibar kazanacaktır.

Öğrencilerin yılmazlık durumları da kariyer seçimleri açısından değerlendirildiğinde kişilerin lider ve güçlü olma durumları arttıkça turizm kariyerini seçme isteklerinin azaldığı görülmüştür. Kişiler liderlik konusunda özgüven sahibi oldukça, yaşamlarına ve yaşamlarında karşılarına çıkabilecek çeşitli durumlar karşısında iyimser oldukça ve çıkabilecek sorunlarla mücadeleye karşı yetenekleri arttıkça turizm sektöründe çalışmayı tercih etmemekte oldukları söylenebilir. Yılmazlık durumu öğrencilerin sektörde kariyer yapma isteklerini açıklamada sınırlı etkiye sahiptir.

Umutsuzluk, kişilerin yalnızca kariyer seçimlerini değil günlük yaşamlarını da etkileyebilen bir durumdur. Çalışmanın bulgularına bakıldığında ise kişilerin hayata karşı umutlu olmaları kariyer seçimlerini etkilemekte olduğu görülmüştür. Ancak umut düzeylerinin yüksek olması kişileri kariyerlerinden uzaklaştırmaktadır. Aynı zamanda çalışmada, öğrencilerin motivasyon kaybı yaşamalarının onların kariyer seçimlerinde herhangi bir etki yaratmadığı görülmüştür.

Çalışma neticesinde görülmektedir ki eğitmenler ve sektör temsilcileri öğrencilerin sektörel kariyerlerinin devam edip etmemesi yönünde oldukça etkindirler. Bu nedenle öğrencilerin sektöre olan olumlu izlenimler edinmesi ve kariyer seçimlerini aldıkları eğitim doğrultusunda devam ettirebilmesi için sektörü sevdirmeli ve olumlu itibar bırakmalıdırlar. Bu çalışma zaman ve destek sınırlıığı açısından Akdeniz Üniversitesi öğrencilerine uygulanmıştır ancak bundan sonraki çalışmalarda daha geniş örneklemle ve başka faktörler ele alınarak incelenebilir.

\section{Kaynakça}

Adıgüzel, O. (2008), Türkiye'de Gençlerin Kariyer Planlamasını Etkileyen Faktörler ve Üniversite Hazırlık Öğrencileri Üzerine Bir Araştırma, Doktora Tezi, Kütahya.

Bland, Z. L. (1986), Career Plans Of Students Enrolled In A Beginning Teacher Education Class At lowa State University, Doctoral Dissertation, lowa State University, lowa.

Braccio, J. (2009), Teacher Rating of Resilience, Social Skills, and Reading and Math Achievement in Hispanic Male Learning Disabled Students, Doctoral Dissertation, Walen University. 
Bulthuis, T. J. (2008), Resilience Factors of University and College Students with Learning Disabilities as Revealed Through Retrospective Interviews, Doctoral Dissertation, Brock University, Ontario.

Ciarrochi J., Heaven P. C.L. (2008), "Learned Social Hopelessness: The Role of Explanatory Style in Predicting Social Support During Adolescence" The Journal of Psychology and Psychiatry, 49 (12), ss.1279-1286.

Coulson, R. (2006), Resilience and Self-Talk in Univerity Students, $A$ Thesis of Master of Science, University of Calgary.

Ergün, E. (2007), İnsan Kaynakları Yönetiminde Kariyer Planlama ve Bir Uygulama, Yüksek Lisans Tezi, İstanbul.

Ferdico D. I. (1999). Hopelessness and Violence in Adolescents, A Clinical Dissertation, Doctoral Dissertation, California.

Gardynik, U. (2008), Defying the Odds: Academic Resilience of Students With Learning Disabilities, $A$ Thesis of Doctor of Philosophy, University of Albertaa.

Greenhaus J. H., Callanan G. A. (1994), Career Management, Harcourt Brace College Publishers, Orlando.

Güneş, M. (2006), Performans Değerlemenin Kariyer Yönetimindeki Yeri ve Önemi, Yüksek Lisans Tezi, İstanbul.

Gürgân, U. (2006), Grupla Psikolojik Danışmanın Üniversite Öğrencilerinin Yılmazlık Düzeylerine Etkisi, Doktora Tezi, Ankara Üniversitesi.

Hammond V. L., Watson, P.J., O'Leary B. J., Cothran L. (2009), "Preliminary Assesstment of Apache Hopefulness: Relationships with Hopelessness and with Collective as well as Personel Self-Esteem" American Indian and Alaska native mental health research, 16 (3), ss. 42-51.

LaHousse, S. F. (2005), "Exploring Educational Resilience Among Mexican Origin University Students Fom Migrant Farmworker Background" A Thesis Degree of Master of Arts Department of Psychology, Michigan State University.

Mccoy, R. M. (2010), An Examination of the Relationship Between Resilience and Symptoms of Posttraumatic Stress Disorder Among Social Work Students at Florida State Üniversity, Doctoral Dissertation, The Florida State University College of Social Work.

Noe R. A. (1999), Insan Kaynaklarının Eğitim ve Gelişimi, (Çev. Canan Çetin), 1. Baskı, İstanbul: Beta.

Oplatka İ. (2010), "Principals İn Late Career: Toward A Conceptualization of Principals' Tasks And Experiences in the Pre-Retirement Period", Eduactional Administration Querterly, 46 (5), ss. 776-815.

Ottekin, N. (2009), Ailelerinden Ayrı Olarak Öğrenim Görmekte Olan Üniversite Öğrencilerinin Benlik Saygısı ve Umutsuzluk Düzeylerinin İncelenmesi, Yüksek Lisans Tezi, Selçuk Üniversitesi, Konya.

Pehlivan, R. (2007), Lisans Düzeyinde Turizm Eğitimi Almakta Olan Öğrencilerin Sektör İle İlgili Tutumlarının Mezuniyet Sonrası Kariyer Seçimlerine Etkisi, Yüksek Lisans Tezi, Aydın.

Şimşek M. Ş., Çelik A., Soysal A., Çelik A. (2004), Kariyer Yönetimi, Gazi Kitabevi, Ankara: Gazi.

Uygur, A. (1998), Örgütlerde Kariyer Geliştirme ve Planlaması: Otel İşletmelerinde Bir Uygulama Konulu Bir Araştırma, Yayınlanmamış Yüksek Lisans Tezi, Ankara.

Üngüren, E. (2007), Lise ve Üniversitelerde Turizm Eğitimi Alan Öğrencilerin Umutsuzluk ve Kaygı Düzeylerinin Çeşitli Değişkenler Açısından Değerlendirilmesi: Antalya'da Bir Uygulama, Yüksek Lisans Tezi, Antalya.

Yıldız, D. (2009), Okul Öncesi Dönem Engelli Çocuğa Sahip Annelerin Çocuklarını Kabullenişleri ile Umutsuzluk Düzeylerinin Karşılaştırılması, Yüksek Lisans Tezi, İstanbul. 